Journal of Bangladesh Academy of Sciences, Vol. 37, No. 2, 131-137, 2013

\title{
CORRELATION AND PATH COEFFICIENT STUDIES OF YIELD AND YIELD ATTRIBUTING CHARACTERS IN PANIKACHU, COLOCASIA ESCULENTA (L.) SCHOTT
}

\author{
K. K. PAUL ${ }^{*}$, M. A. BARI AND S. C. DEBNATH \\ Institute of Biological Sciences, Rajshahi University, Rajshahi -6205, Bangladesh
}

\begin{abstract}
The study was made to identify the association of yield and stolon characters and their direct and indirect effects in panikachu, Colocasia esculenta (L.) Schott. The stolon number, single stolon weight, total stolon weight, stolon length, length and breadth of corm and weight of corm showed positive correlation with yield per plant of which single stolon weight and corm breadth showed significant positive correlation with yield per plant at phenotypic level. Stolon breadth exhibited significant positive correlation with yield per plant at genotypic level. The residual effect in the genotypic level was 0.2205 which indicated this character contributed $78 \%$ of the yield. Results obtained suggested that maximum emphasis should be given on characters in selecting panikachu genotypes with higher yield per plant and the residual effect in phenotypic level was 0.4235 indicating $58 \%$ variability contributed by these characters.
\end{abstract}

Key words: Colocasia esculenta, Genotypic correlation, Phenotypic, Path coefficient

\section{INTRODUCTION}

Panikachu, Colocasia esculenta (L.) Schott belongs to the family Araceae and the edible species are referred to as panikachu (Hossain et al. 1983, Zettler et al. 1989) in Bangladesh. It is a herbaceous plant, and the plant has a central corm (lying just below the soil surface) from which stolons grow laterally. The sterile appendage is a distinguishing taxonomic characteristic between dasheen and eddoe types of taro. In Bangladesh, a total of 108 aroid germplasms have been recorded of which 69 panikachu were reported (BARI 2001). They are grown for their edible corms; in some cultivars the leaves, petioles and flowers are eaten as vegetables. It is also a rich source of calcium, phosphorus, iron, vitamin $\mathrm{C}$, thiamine, riboflavin and niacin. To meet the need for more food because of increase in population it will be necessary to make better use of a broader range of a country's plant genetic diversity. Many species of this family has already been extinct and some are vulnerable and some species are available at present. Therefore, the knowledge of association of component characters with yield is of great importance to

* Corresponding author: <krshnnd@yahoo.com>. 
plant breeders as it helps in their selection with more precision and accuracy. Path coefficient analysis 'further permits the partitioning of the correlation coefficients into components of direct and indirect factor of association and provides an effective tool in finding out the direct and indirect contribution of different contributing characters towards yield (Falconar 1989). So, the present study was undertaken to find out nature and magnitude of relationships between yield and yield components and direct and indirect effects of the component characters on yield per plant of aqua edible aroid.

\section{MATERIALS AND METHODS}

In 2005-2006 edible aroid accessions were collected from aroid growing districts of Barisal, Bogra, Dhaka, Jessore, Joypurhat, Munshiganj, Mymensingh, Rajshahi and Satkhira in Bangladesh. Collected 485 propagules, mainly plantlets and suckers, were maintained at the experimental farm of the Institute of Biological Sciences of Rajshahi University, Rajshahi, Bangladesh in 2006. For cultivation of this aroid all recommended agricultural practices were followed. The soil was part of Level Barind agroecological zone marked by sandy loam with $\mathrm{pH} 6.5$.

The experiment was set up in a Randomized Complete Block Design (RCBD) with three replication of plot. In each experimental plot size was $27 \mathrm{~m}^{2}$ and plant propagules were planted with row to row and plant to plant spacing was $0.75 \mathrm{~m}$ and $0.60 \mathrm{~m}$, respectively. Each plot covered with total 60 plantlets with six lines. The plantlets were sown on March, 2006. Two healthy selected propagules were planted per hill during plantation and finally a single healthy plant was maintained. The characters, stolon number (STN), stolon length (STL), stolon breadth (STB), single stolon weight (SSTW), total stolon weight (TSTW), corm length (CRL), corm breadth (CRB), corm weight (CRW) and yield per plant (YPP) were selected for data collection. When the vegetative growth is in climax then the agro-morphological data were collected. When plant and vegetative growth is very stunted, leaves become yellowish, dry and dropping then the quantitative parameters were observed and data were recorded following descriptors of Taro with necessary modifications (IPGRI 1999).

The collected data were analyzed following the biometrical techniques of analysis developed by Mather (1949) using the SPSS and MS excel software. For the purpose of correlation and path coefficient analysis, the analysis of variance, the components of variances viz. genotypic variance $\left(\sigma_{\mathrm{g}}^{2}\right)$, phenotypic variance $\left(\sigma_{\mathrm{p}}^{2}\right)$ and environment variance $\left(\sigma_{\mathrm{e}}^{2}\right)$ and covariance between all possible pairs of characters separately were estimated following the methods as described by Singh and Chaudhary (1977). The path coefficient analysis was done by using formula (Wright 1921) extended by Dewey and $\mathrm{Lu}$ (1959). 


\section{RESULTS AND DISCUSSION}

The mean data of yield and yield contributing characters showing in Table 1 and correlation coefficient analysis were computed both at genotypic and phenotypic levels to measure the association of yield contributing characters are present in Table 2.

Stolon number showed highly significant negative effect with stolon breadth. Single stolon weight exhibited significant and negative effects with stolon breadth. Total stolon weight character showed highly significant positive effects with stolon breadth and yield per plant. Stolon length showed highly negative and significant effect with stolon breadth. Stolon breath showed highly significant and positive association was observed with corm length, corm breadth, corm weight and yield per plant.

Table 1. Mean performance of yield and yield contributing characters of panikachu, Colocasia esculenta

\begin{tabular}{lccccccccccccc}
\hline Cultivars & $\begin{array}{c}\text { PLH } \\
\mathrm{cm}\end{array}$ & $\begin{array}{c}\text { LEL } \\
\mathrm{cm}\end{array}$ & $\begin{array}{c}\text { LEB } \\
\mathrm{cm}\end{array}$ & LEN & STN & $\begin{array}{c}\text { SST } \\
\text { W g. }\end{array}$ & $\begin{array}{c}\text { TSTW } \\
\mathrm{g} .\end{array}$ & $\begin{array}{c}\text { STL } \\
\mathrm{cm}\end{array}$ & $\begin{array}{c}\text { STB } \\
\mathrm{cm}\end{array}$ & $\begin{array}{c}\text { CRL } \\
\mathrm{cm}\end{array}$ & $\begin{array}{c}\text { CRB } \\
\mathrm{cm}\end{array}$ & $\begin{array}{c}\text { CRW } \\
\mathrm{kg}\end{array}$ & $\begin{array}{c}\text { YPP } \\
\mathrm{kg}\end{array}$ \\
\hline $\begin{array}{l}\text { 1.Shola } \\
\text { kachu } \\
\text { (tall) }\end{array}$ & 160.46 & 48.86 & 22.63 & 5.40 & 15.2 & 74.30 & 1138.47 & 71.03 & 3.00 & 39.8 & 27.97 & 1.40 & 2.55 \\
$\begin{array}{l}\text { 2.Kalo } \\
\text { kachu }\end{array}$ & & & & & & & & & & & & & \\
(small) & & & & & & & & & & & & & \\
3.Narikel & 95.86 & 32.86 & 21.36 & 5.03 & 10.5 & 45.03 & 466.9 & 83.63 & 2.78 & 19.2 & 19.47 & 0.394 & 0.851 \\
kachu & & & & & & & & & & & & & \\
greenlati & & & & & & & & & & & & & \\
Mean & 115.26 & 24.73 & 6.10 & 18.8 & 50.36 & 945.87 & 86.86 & 3.43 & 46.9 & 33.87 & 2.19 & 3.13 \\
\pm S.E & 3.62 & 0.890 & 0.399 & 0.093 & 0.455 & 1.80 & 39.40 & 3.88 & 0.079 & 1.50 & 0.751 & 0.090 & 0.116 \\
S.D. & 34.32 & 8.445 & 3.782 & 0.877 & 4.32 & 17.05 & 373.6 & 36.8 & 0.749 & 14.24 & 7.12 & 0.857 & 1.10 \\
C.D. at & 11.11 & 2.732 & 1.225 & 0284 & 1.397 & 5.526 & 120.9 & 11.91 & 0.243 & 4.605 & 2.306 & 0.276 & 0.356 \\
0.05 0.01 & 17.34 & 4.263 & 1.911 & 0.443 & 2.179 & 8.622 & 188.7 & 18.58 & 0.378 & 7.185 & 3.597 & 0.431 & 0.556 \\
\hline
\end{tabular}

Plant height (PLH), leaf length (LEL), leaf breath(LEB), leaf number (LEN), stolon number (STN) stolon length (STL), stolon breadth (STB), single stolon weight (SSTW), total stolon weight (TSTW), corm length (CRL), corm breadth (CRB), corm weight (CRW) and yield per plant (YPP).

Stolon number exhibited highly significant and positive effects with single stolon weight, stolon breadth and corm breadth. Single stolon weight showed highly significant and positive effects with total stolon weight, stolon length, stolon breadth, corm length, corm breadth and yield per plant. Total stolon weight exhibited highly significant and positive effects with stolon breadth, corm length, corm breadth. Stolon length exhibited highly significant and positive effects with each stolon breadth, corm breadth. The relationship of stolon breadth exhibited highly significant negative effects with corm length, corm breadth and yield per plant. Only significant and positive effect was found with corm weight. The correlation of corm length showed significant and positive correlation with corm breadth. Highly significant and positive correlation of corm breadth was found with yield per plant. 
Path coefficient analysis was computed both at genotypic and phenotypic levels to measure the direct and indirect effects of yield contributing characters on the end product (yield per plant) and are present in Table 2.

Table 2. Phenotypic (below the diagonal) and genotypic (above the diagonal) correlation coefficients for yield and some yield contributing characters of panikachu, $C$. esculenta (L) Schott.

\begin{tabular}{|c|c|c|c|c|c|c|c|c|c|c|}
\hline \multicolumn{2}{|c|}{ Characters } & \multirow{2}{*}{$\frac{\text { STN }}{1}$} & \multirow[t]{2}{*}{ SSTW } & \multirow[t]{2}{*}{ TSTW } & \multirow[t]{2}{*}{ STL } & \multirow[t]{2}{*}{ STB } & \multirow[t]{2}{*}{ CRL } & \multirow[t]{2}{*}{ CRB } & \multirow[t]{2}{*}{ CRW } & \multirow[t]{2}{*}{ YPP } \\
\hline STN & G & & & & & & & & & \\
\hline & $\mathrm{P}$ & & & & & & & & & \\
\hline \multirow[t]{2}{*}{ SSTW } & $\mathrm{G}$ & -0.242 & 1 & & & & & & & \\
\hline & $\mathrm{P}$ & $0.514^{*}$ & & & & & & & & \\
\hline \multirow[t]{2}{*}{ TSTW } & G & -0.081 & -0.226 & 1 & & & & & & \\
\hline & $\mathrm{P}$ & 0.360 & $0.628 * *$ & & & & & & & \\
\hline \multirow[t]{2}{*}{ STL } & G & -0.137 & 0.225 & -0.128 & 1 & & & & & \\
\hline & $\mathrm{P}$ & 0.343 & $0.619 * *$ & 0.431 & & & & & & \\
\hline \multirow[t]{2}{*}{ STB } & G & $-0.742 * *$ & $-0.620^{* *}$ & $0.777 * *$ & $-0.869^{* *}$ & 1 & & & & \\
\hline & $\mathrm{P}$ & $0.692 * *$ & $0.980 * *$ & $0.680 * *$ & $0.990 * *$ & & & & & \\
\hline \multirow[t]{2}{*}{ CRL } & G & -0.123 & -0.264 & -0.277 & -0.158 & $0.647 * *$ & 1 & & & \\
\hline & $\mathrm{P}$ & 0.460 & $0.605^{* *}$ & $0.654 * *$ & 0.423 & $-0.730 * *$ & & & & \\
\hline \multirow[t]{2}{*}{ CRB } & G & -0.226 & 0.434 & -0.254 & -0.285 & $0.750^{* *}$ & -0.233 & 1 & & \\
\hline & $\mathrm{P}$ & $0.586^{*}$ & $0.889^{* *}$ & $0.616^{* *}$ & $0.606^{* *}$ & $-0.750^{* *}$ & $0.686^{* *}$ & & & \\
\hline \multirow[t]{2}{*}{ CRW } & G & -0.0120 & -0.159 & -0.059 & -0.091 & $0.680++$ & -0.058 & -0.121 & 1 & \\
\hline & $\mathrm{P}$ & 0.263 & 0.351 & 0.278 & 0.255 & $0.850^{* *}$ & 0.298 & 0.420 & & \\
\hline \multirow[t]{2}{*}{ YPP } & G & -0.034 & -0.187 & $0.456 *$ & -0.106 & $0.850^{* * *}$ & -0.086 & -0.168 & -0.080 & 1 \\
\hline & $\mathrm{P}$ & 0.308 & $0.451^{*}$ & 0.350 & 0.321 & $-0.860^{* *}$ & 0.352 & $0.750 * *$ & 0.256 & \\
\hline
\end{tabular}

* Significant at $0.05 \%$ level. ** Significant at $0.01 \%$ level.

Stolon number exhibited high direct effects on yield per plant. Each stolon weight showed positive direct effect on yield per plant. It also showed positive and indirect effects via stolon number, total stolon weight, corm length and corm breadth. Total stolon weight showed positive direct effects on yield per plant. It also showed positive and indirect effect through corm length and corm breadth. Each stolon length showed positive direct effect on yield per plant. Indirect and positive stolon number, total stolon weight, stolon length, corm length and corm breadth. Corm length showed direct and positive effect on yield per plant. It also exhibited positive and indirect effects through total stolon weight and corm breadth. The corm breadth showed high positive direct effect on yield per plant. It also exhibited positive and indirect effects through stolon number, single stolon weight, total effects also showed through petiole breadth and corm breadth. The stolon breadth expressed very low direct and positive effect on yield per plant. Positive and indirect effects also found through stolon weight and corm length. Corm weight exhibited positive direct effect on yield per plant. 
Table 3. Direct (diagonal bold) and indirect effects for yield and some yield contributing characters of pani kachu, Colocasia esculenta in genotypic level(G) and phenotypic level (P).

\begin{tabular}{|c|c|c|c|c|c|c|c|c|c|c|}
\hline \multicolumn{2}{|c|}{ Characters } & \multirow{2}{*}{$\frac{\text { STN }}{0.5496}$} & \multirow{2}{*}{$\frac{\text { SSTW }}{0.0249}$} & \multirow{2}{*}{$\frac{\text { TSTW }}{0.0463}$} & \multirow{2}{*}{$\frac{S R L}{0.0270}$} & \multirow{2}{*}{$\frac{\text { STB }}{0.0115}$} & \multirow{2}{*}{$\frac{\text { CRL }}{0.0538}$} & \multirow{2}{*}{$\frac{\text { CRB }}{0.0980}$} & \multirow{2}{*}{$\frac{\text { CRW }}{0.0010}$} & \multirow{2}{*}{$\begin{array}{l}\text { Corr YPP } \\
-0.690 * *\end{array}$} \\
\hline STN & $\mathrm{G}$ & & & & & & & & & \\
\hline & $P$ & 1.1278 & 0.6918 & 0.2292 & 0.0990 & 0.0743 & 0.4140 & 0.8642 & 0.1682 & 0.308 \\
\hline SSTW & G & 0.1330 & 0.1027 & 0.1292 & 0.0443 & 0.0521 & 0.1154 & 0.1878 & 0.0129 & -0.187 \\
\hline & $\mathrm{P}$ & 0.5797 & 1.3458 & 0.3999 & 0.1787 & 0.2124 & 0.5445 & 1.3110 & 0.2245 & $0.451 *$ \\
\hline TSTW & G & 0.0445 & 0.0232 & 0.5715 & 0.0252 & 0.0653 & 0.1211 & 0.1102 & 0.0048 & $0.456 *$ \\
\hline & $\mathrm{P}$ & 0.4060 & 0.8452 & 0.6368 & 0.1244 & 0.1474 & 0.5886 & 0.9084 & 0.1778 & 0.350 \\
\hline \multirow[t]{2}{*}{ STL } & G & 0.0753 & 0.0231 & 0.0732 & 0.1969 & 0.0730 & 0.0691 & 0.1236 & 0.0074 & -0.106 \\
\hline & $P$ & 0.3868 & 0.8331 & 0.2745 & 0.2886 & 0.2217 & 0.3807 & 0.8937 & 0.1631 & 0.321 \\
\hline \multirow[t]{2}{*}{ STB } & G & 0.4078 & 0.0637 & 0.4441 & 0.1711 & 0.0840 & 0.2798 & 0.3253 & 0.0552 & $0.850 * *$ \\
\hline & $\mathrm{P}$ & 0.7804 & 1.3189 & 0.4330 & 0.2973 & 0.2167 & 0.6570 & 1.1060 & 0.5436 & $-0.860 * *$ \\
\hline \multirow[t]{2}{*}{ CRL } & G & 0.0676 & 0.0271 & 0.1583 & 0.0311 & 0.0543 & 0.4373 & 0.1011 & 0.0047 & -0.086 \\
\hline & $\mathrm{P}$ & 0.5188 & 0.8142 & 0.4165 & 0.1221 & 0.1582 & 0.9001 & 1.0116 & 0.1906 & 0.352 \\
\hline \multirow[t]{2}{*}{ CRB } & G & 0.1242 & 0.2480 & 0.1452 & 0.0561 & 0.0630 & 0.1019 & 0.4338 & 0.0098 & -0.168 \\
\hline & $P$ & 0.6609 & 0.5661 & 0.3923 & 0.1749 & 0.1625 & 0.6174 & 1.4747 & 0.2686 & $0.750 * *$ \\
\hline \multirow[t]{2}{*}{ CRW } & G & 0.0066 & 0.0163 & 0.0337 & 0.0179 & 0.0571 & 0.0254 & 0.0525 & 0.0812 & -0.080 \\
\hline & $P$ & 0.2966 & 0.4724 & 0.1770 & 0.0736 & 0.1842 & 0.2682 & 0.6194 & 0.6396 & 0.256 \\
\hline
\end{tabular}

Residual effect $=0.2205(\mathrm{G})$. Residual effect $=0.423(\mathrm{P})$. $*$ Significant at 0.05 level. ${ }^{*} *$ Significant at 0.01 level.

Stolon number showed high positive direct effect on yield per plant. It also showed positive and indirect effects through single stolon weight, total stolon weight, corm length, corm breadth and corm weight. Single stolon weight showed also high and positive effects on yield per plant. Single stolon weight also showed positive and indirect effects via stolon number, total stolon weight, stolon length, stolon breadth, corm length, corm breadth and corm weight. Total stolon weight exhibited high positive direct effect on yield per plant. Positive and indirect effects also found through stolon number, single stolon weight, stolon length, stolon breadth, corm length, corm breadth and corm weight. Single stolon length exhibited and positive direct effect on yield per plant. It showed positive and indirect effects through stolon number, single stolon weight, total stolon weight, single stolon breadth, corm length, corm breadth and corm weight. The stolon breadth showed low positive effects on yield per plant. It showed indirect and positive effect via stolon number, single stolon weight, total stolon weight, stolon length, corm length, corm breadth and corm weight. Corm length showed high and positive direct effect on yield per plant. It exhibited positive and indirect effects through stolon number, single stolon weight, total stolon weight, stolon length, stolon breadth, corm breadth and corm weight. The corm breadth exhibited high positive direct effect on yield per plant. Indirect effects also found positive through stolon number, single stolon weight, total 
stolon weight, stolon length, stolon breadth, corm breadth and corm weight. Corm weight showed high positive direct effect on yield per plant. Positive and indirect effects also found via stolon number, single stolon weight, total stolon weight, stolon breadth, corm length and corm breadth.

Correlation study showed the wide spectrum of relationship in respect of yield per plant and the characters themselves. Positive and significant correlation was found between stolon characters. Corm characters (corm length and breadth) also showed significant association among them and yield per plant. In the genotypic level stolon length vs corm breadth, total stolon weight vs stolon breadth and yield per plant. In general out of total association 20 showed phenotypic correlations higher in magnitude than their corresponding genotypic correlations indicated environmental factors played a significant role in the expression of association. The path coefficient analysis was carried out for eight characters in panikachu to investigate the direct and indirect effect towards yield and yield contributing characters. In genotypic level relatively moderate to high direct effects was expressed by, total stolon weight, stolon number, corm length and corm breadth. In the phenotypic level corm breadth followed by single stolon weight, total stolon weight stolon number, and corm length,corm breadth showed positive and highest direct effect toward yield per plant. Residual effect in both cases indicates that there has a positive chance for selection for cultivars development. Research works of some researchers were similar to our results are discussed here. Akoroda (1984) worked on seven agronomic traits like plant leafiness, number of tubers per hills and tuber yield in yellow yam and observed positive and highly significant correlation of tuber yield with plant, leafiness, shoot height and vine dry weight. Chand et al. (1987) studied in taro that at the magnitude of genotypic correlation coefficients was in general higher than phenotypic ones. Yield was positively and significantly correlated with L/B ratio of leaves and number of suckers per plant at both genotypic and phenotypic levels. High positive correlation between plant height and size of corms, L/B ratio and size of corm was observed at genotypic level. Mahon et al. (1990) showed that the characters such as mean weight of cormels/plant, number of cormels/plant and LAI were positively and significantly correlated with yield. Goenaga (1994) observed yield per plant was significantly and positively correlated with most of characters at both phenotypic and genotypic levels in tanier plants. Pandey et al. (1996) studied 31 genotypes of taro with 8 yield contributed characters and observed that yield per plant was significantly and positively correlated with most of character at both phenotypic and genotypic levels. Dwivedi and Sen (1999) studied thirty genotypes of taro for correlation and observed that cormel yield had positive and significant association with the length and girth of main sucker, number of cormels per plant an corm weight but it was negatively correlated with corm/cormel ratio. Velayudhan et al. (2000) found that the characters cormel number, 
cormel thickness, plant height, leaf length and leaf width had higher positive correlation with cormel yield whereas leaf number was negatively correlated with yield. Cheema et al. (2007) studied in arvi total yield per plant was positively and significantly correlated with number of corms and cormels per plant and corm length.

\section{REFERENCES}

Akroda, M. O. 1984. Variability, repeatability, character correlation and path coefficient analysis in yellow Yam. TAG 69: 217-221.

BARI, 2001. Varietal improvement and development of production package of aroids in diversified areas in Bangladsh, A final report. Tuber crop Research Centre, Joydebpur, Gazipur. p. 1.

Chand, B., R.C. Jaiawal and N.C.Gautam. 1987. Genetic variability and correlation studies in Colocasia (C. esculenta L.). Haryana J. Hort. Sci. 16: 134-139.

Cochran, W.G. and G.M. Cox. 1960. Experimental design. $2^{\text {nd }}$ edition. John Willey and Sons, Inc. New York

Dewey, D.I. and K.H. Lu. 1959. A correlation and path coefficient analysis of components of created wheat grass seed production. Agron. J. 52:515-518

Dwivedi, A. K and H. Sen. 1997. Genetic variability and genetic advance relating to some yield attributing traits in taro (Colocasia esculenta). J. Root crops 23:119-123.

Falconer, D.S. 1989. Introduction to quantitative Genetics, 3rd ed. John Wiley and Sons, New York,

Hossain, M. M., M. Hussain, B. Choudhury, A. Hussain and M.M. Rashid. 1983. Study of yield potential and nutrient quality of some cultivars of panikachu. Bangladesh Hort. 11: 15-24.

IPGRI. 1999. Descriptors for taro (Colocasia esculenta). International Plant Genetic Research Institute, Rome, Italy.

Mather, K. 1949. Biometrical genetics, Dover publication. Inc. New York.

Pandey, G., V. K.Dhobal and R.L. Sapra. 1996. Genetic variability, correlation and path analysis in Taro (Colocasia esculenta). J. Hill. Res. (India) 9: 299-302.

Singh, R.K. and B.D. Chaudhary. 1977. Biometrical methods in quantitative genetic analysis .Kalnani publishers, New Delhi, India. pp. 39 - 68.

Wright, S. 1921. Correlation and causation. J. Agric. Res. 20: 557-585.

Zettler, F.W., G. V. H. Jackson and F. A. Frison. 1989. FAO/IBPGR.Technical Guidlines for the safe movement of Edible Aroid Germplasm. FAO, Rome /IBPGR, Rome Italy. p. 24. 